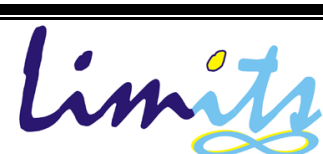

Limits: Journal of Mathematics and Its Applications

E-ISSN: 2579-8936

P-ISSN: 1829-605X

Vol. 18, No. 1, Mei 2021, 79-94

DOI: http://dx.doi.org/10.12962/limits.v18i1.7705

\title{
Himpunan Fuzzy dan Rough Sets
}

\author{
Bijan Davvaz', Imam Mukhlash ${ }^{2, *}$, Soleha ${ }^{2}$ \\ ${ }^{1}$ Department of Mathematics, Yazd University, Yazd, Iran \\ e-mail: davvaz@yazd.ac.ir \\ ${ }^{2}$ Departemen Matematika, Institut Teknologi Sepuluh Nopember, Kampus ITS, Sukolilo-Surabaya 60111, \\ Indonesia \\ e-mail: imamm@matematika.its.ac.id, seha 07@matematika.its.ac.id
}

Diajukan: 4 September 2020, Diperbaiki: 4 Oktober 2020, Diterima: 22 April 2021

\begin{abstract}
Konsep himpunan fuzzy diperkenalkan oleh Zadeh pada tahun 1965. Himpunan fuzzy adalah model matematika dari data kualitatif atau kuantitatif yang bersifat samar, yang sering dihasilkan melalui bahasa alami. Model ini didasarkan pada generalisasi konsep himpunan klasik dan fungsi karakteristiknya. Himpunan fuzzy intuitionistic adalah himpunan yang elemen-elemennya memiliki derajat keanggotaan dan non-keanggotaan. Himpunan fuzzy intuitionistic diperkenalkan oleh Atanassov pada tahun 1983 sebagai perluasan dari himpunan fuzzy. Di sisi lain, konsep rough set diusulkan oleh Pawlak pada tahun 1982. Sejak itu, topik ini telah dikaji di banyak paper. Tujuan keseluruhan dari paper ini adalah untuk menyajikan pengantar beberapa konsep utama terkait dengan himpunan fuzzy, himpunan fuzzy intuitionistic dan rough set. Pada paper ini akan dikaji beberapa topik berikut: crisp sets dan fungsi karakteristik, himpunan fuzzy, himpunan fuzzy intuitionistic, rough sets, dan rough sets probabilistik.

Kata kunci: Fungsi karakteristik, himpunan fuzzy, himpunan fuzzy intuitionistic, aproksimasi bawah dan atas, rough set.

Abstract

The concept of a fuzzy set was introduced by Zadeh in 1965. Fuzzy set is a mathematical model of vague qualitative or quantitative data, frequently generated by means of the natural language. The model is based on the generalization of the classical concepts of set and its characteristic function. Intuitionistic fuzzy sets are sets whose elements have degrees of membership and non-membership. Intuitionistic fuzzy sets have been introduced by Atanassov in 1983 as an extension fuzzy sets. On the other hand, the concept of rough set was proposed by Pawlak 1982. Since then the subject has been investigated in many papers. The overall aim of this paper is to present an introduction to some of main concepts related to fuzzy sets, intuitionistic fuzzy sets and rough sets. We investigate Crisp sets and characteristic functions, fuzzy sets, intuitionistic fuzzy sets, rough sets and probabilistic rough sets.
\end{abstract}

Keywords: Characteristic function, fuzzy set, intuitionistic fuzzy set, lower and upper approximations, rough set.

\section{Crisp Set dan Fungsi Karakteristik.}

Teori himpunan merupakan salah satu cabang logika matematika yang mempelajari konsep himpunan, yang secara informal didefinisikan sebagai kumpulan objek-objek. Walaupun beberapa tipe objek dapat dikumpulan dalam suatu himpunan, teori himpunan seringkali diaplikasikan pada objek-objek yang relevan dengan matematika. Bahasa dari teori himpunan dapat digunakan untuk 
mendefinisikan hampir semua objek matematika. Studi modern tentang teori himpunan diawali oleh George Cantor dan Richard Dedekin pada tahun 1870an.

Jika $X$ adalah sebuah himpunan (yang mana angota-anggotanya dapat berupa bilangan atau objek-objek yang lain) dan $x$ adalah anggota dari $X$, maka dapat ditulis $x \in X$. Sebaliknya, jika $x$ bukan anggota dari $X$ maka dapat ditulis dengan $x \notin X$. Untuk sebuah sifat $p$ dan $x$ adalah anggota dari $X$, ditulis $p(x)$ untuk menyatakan bahwa $x$ mempunyai sifat $p$. Suatu himpunan bisa didefinisikan oleh sebuah sifat. Notasi $A=\{x \in X: p(x)\}$ menyatakan bahwa himpunan $A$ memuat semua anggota $x$ dari $X$ yang memiliki sifat $p$. Himpunan kosong $\varnothing$ adalah sebuah himpunan yang tidak mempunyai anggota. Pertimbangkan sebuah gagasan tentang subset dan operasi himpunan (union/gabungan, intersection/irisan, dan komplemen) dari suatu himpunan beserta aturan dasar yang mengatur operasi-operasi ini.

Andaikan bahwa $A$ dan $B$ adalah dua himpunan, maka

(1) $A$ disebut subset dari $B$ dan ditulis $A \subseteq B$ jika setiap anggota $A$ juga merupakan anggota $B$.

(2) Union/gabungan dari $A$ dan $B$, dinyatakan dengan $A \cup B$, adalah himpunan dari semua elemen $x$ sedemikian hingga $x$ anggota dari paling sedikit salah satu dari $A$ atau $B$.

(3) Intersection/irisan dari $A$ dan $B$, dinyatakan dengan $A \cap B$, adalah himpunan dari semua elemen $x$ sedemikian hingga $x$ anggota dari $A$ dan $B$.

(4) Komplemen dari $A$ mengacu pada elemen-elemen yang bukan anggota $A$ dan dinyatakan dengan $A^{c}$.

Definisi 1. Misalkan $X$ adalah himpunan semesta dan $A \subseteq X$. Maka,

$$
\begin{aligned}
\chi_{A}: X \rightarrow[0,1] \\
\chi_{A}= \begin{cases}1, \text { jika } x & \in A \\
0, \text { jika } x & \notin A\end{cases}
\end{aligned}
$$

disebut fungsi karakteristik dari himpunan $A$.

Teorema 2 dan 3 dapat membantu untuk memahami dengan lebih baik gagasan tentang himpunan fuzzy sebagai sebuah generalisasi dari himpunan biasa.

Teorema 2. Misalkan $X$ adalah himpunan semesta dan $A, B \subseteq X$. Maka

$$
\chi_{A}=\chi_{B} \leftrightarrow A=B
$$

Teorema 3. Misalkan $X$ adalah himpunan semesta dan $A, B \subseteq X$. Maka

1. $\chi_{A \cap B}(x)=\min \left\{\chi_{A}(x), \chi_{B}(x)\right\}$, untuk setiap $x \in X$;

2. $\chi_{A \cup B}(x)=\max \left\{\chi_{A}(x), \chi_{B}(x)\right\}$, untuk setiap $\left.x \in X\right\}$;

3. $\chi_{A^{c}}(x)=1-\chi_{A}(x)$, untuk setiap $x \in X$. 


\section{$2 \quad$ Apakah Himpunan Fuzzy?}

Proses-proses yang dimodelkan dalam dunia nyata seringkali tidak eksak. Biasanya, realitas yang terkait dengan ketidakpastian tidak dapat dimodelkan sebagaimana adanya dan ada keterbatasan dalam melakukan pemodelan. Himpunan fuzzy memungkinkan seseorang untuk bekerja dalam situasi yang tidak pasti dan ambigu dan memecahkan masalah yang tidak diharapkan atau masalah dengan informasi yang tidak lengkap.

Himpunan fuzzy adalah himpunan yang elemen-elemennya memiliki derajat keanggotaan. Himpunan fuzzy telah diperkenalkan oleh L. A. Zadeh (1965) sebagai perluasan dari pengertian himpunan klasik [1]. Juga, lihat [2].

Teori fuzzy menggunakan variabel linguistik yang nilainya adalah kata-kata fuzzy, atau lebih bersifat ekspresi -alih-alih angka-, yang berakar pada bahasa alami. Kata-kata fuzzy tidak akurat tetapi sangat mudah dimengerti dan digunakan secara luas dalam bahasa sehari-hari.

\begin{tabular}{|l|l|}
\hline Ketinggian & Pendek, rata-rata,tinggi,... \\
\hline Usia & Bayi, anak-anak, remaja, dewasa, separuh baya, tua,... \\
\hline Suhu & Sangat dingin, dingin, sejuk, panas, sangat panas,... \\
\hline Keamanan & Rendah, sedang, tinggi,... \\
\hline
\end{tabular}

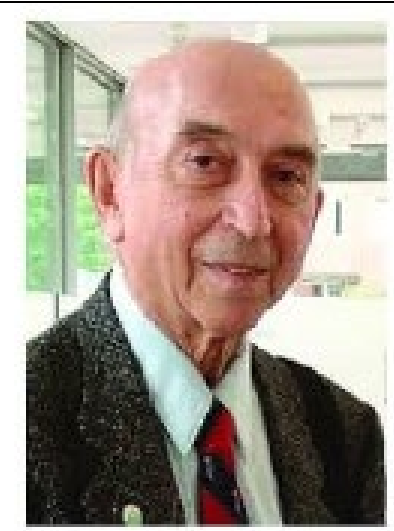

Gambar 1. L.A Zadeh

Dalam teori himpunan klasik, keanggotaan unsur-unsur dalam suatu himpunan dinilai berdasarkan kondisi bivalen: suatu unsur termasuk milik suatu himpunan atau bukan. Sebaliknya, teori himpunan fuzzy mengijinkan penilaian bertahap dari keanggotaan elemen dalam himpunan; hal ini dijelaskan dengan bantuan fungsi keanggotaan yang dinilai dalam interval bilangan real $[0,1]$. Himpunan fuzzy menggeneralisasi himpunan klasik, karena fungsi karakteristik himpunan klasik adalah kasus khusus dari fungsi keanggotaan himpunan fuzzy, jika himpunan fuzzy hanya mengambil nilai 0 atau 1. 
Dalam kehidupan sehari-hari, biasanya ingin dicari pendapat dari orang-orang profesional/ahli dengan kualifikasi terbaik, misalnya, dokter medis terbaik dapat memberikan diagnostik terbaik, pilot terbaik dapat memberikan saran navigasi terbaik untuk pesawat, dan lainlain. Oleh karena itu, sangat diharapkan untuk memasukkan pengetahuan para ahli ini ke dalam beberapa sistem otomatis sehingga akan membantu orang lain untuk membuat keputusan yang tepat yang (hampir) sebaik keputusan yang dibuat oleh para ahli terkemuka. Dengan mengingat tujuan ini, tugas kita adalah merancang sistem yang akan memberikan saran terbaik dari para ahli terbaik di bidangnya. Namun, salah satu rintangan utama dari penggabungan ini adalah bahwa para ahli biasanya tidak dapat menggambarkan pengetahuan mereka dengan menggunakan istilah yang benar dan tepat. Misalnya, untuk menggambarkan ukuran suatu jenis tumor, seorang dokter jarang menggunakan angka pasti. Sebaliknya dia akan mengatakan sesuatu seperti "ukurannya antara 1,4 dan 1,6 cm ". Selain itu, seorang ahli biasanya akan menggunakan beberapa kata dari bahasa alami, misalnya, "ukuran tumor kira-kira $1,5 \mathrm{~cm}$, dengan kesalahan sekitar $0,1 \mathrm{~cm}$ ". Dengan demikian, dalam keadaan seperti itu, cara memformalkan pernyataan yang diberikan oleh seorang pakar merupakan salah satu tujuan utama logika fuzzy.

Contoh 1. Misalkan $X$ adalah himpunan semua mahasiswa Institut Teknologi Sepuluh Nopember, dan misalkan

$$
\begin{aligned}
& A=\text { Himpunan semua mahasiswa perempuan; } \\
& B=\text { Himpunan semua mahasiswa Departemen Matematika; } \\
& C=\text { Himpunan semua mahasiswa Departemen Statistika; } \\
& D=\text { Himpunan semua mahasiswa cerdas; } \\
& E=\text { Himpunan semua mahasiswa tinggi. }
\end{aligned}
$$

Himpunan-himpunan $A, B$, dan $C$ adalah himpunan crisp, sedangkan himpunan $D$ dan $E$ bersifat samar/kabur. Jadi, $D$ dan $E$ adalah himpunan fuzzy.

Definisi 4. Misalkan X suatu himpunan. Suatu subset fuzzy A dari X dikarakteristikkan oleh sebuah fungsi keanggotaan $\mu_{A}: X \rightarrow[0,1]$ yang terkait dengan setiap titik $x \in X$ dengan tingkat atau derajat keanggotaan $\mu_{A}(x) \in[0,1]$.

Contoh 2. Didefinisikan suatu fungsi keanggotaan yang mungkin untuk suatu subset fuzzy dari "bilangan real yang dekat dengan nol” sebagai berikut

$$
\mu_{A}(x)=\frac{1}{1+10 x^{2}}
$$

Dengan menggunakan fungsi ini, dapat ditentukan derajat keanggotaan dari setiap bilangan real dalam subset fuzzy ini, yang menandakan derajat kedekatan suatu bilangan ke 0. Sebagai contoh, bilangan 3 mempunyai derajat keanggotaan 0.01, mempunyai tingkat kedekatan 0.09 ke 
0 , bilangan 0.25 mempunyai derajat kedekatan 0.62 dengan 0 , dan bilangan 0 mempunyai derajat keaggotaan 1. Secara intuitif diharapkan bahwa dengan melakukan beberapa operasi pada fungsi yang sesuai dengan himpunan bilangan yang mendekati 0 , bisa diperoleh fungsi yang mewakili himpunan bilangan yang sangat dekat dengan 0 . Satu cara yang mungkin untuk menyelesaikan hal ini adalah dengan mengkuadratkan fungsi, yaitu,

$$
\mu_{A}(x)=\left(\frac{1}{1+10 x^{2}}\right)^{2}
$$

Fungsi ini dapat juga digeneralisasi ke keluarga fungsi yang mewakili himpunan bilangan real yang dekat dengan bilangan tertentu $a$ sebagai berikut:,

$$
\mu_{A}(x)=\frac{1}{1+10(x-a)^{2}} .
$$

Definisi 5. Misalkan A dan B subset fuzzy dari X.

- $A \subseteq B$ jika dan hanya jika $\mu_{A}(x) \leq \mu_{B}(x)$ untuk semua $x \in X$.

- $A=B$ jika dan hanya jika $\mu_{A}(x)=\mu_{B}(x)$ untuk semua $x \in X$.

- $C=A \cup B$ jika dan hanya jika $\mu_{C}(x)=\max \left\{\mu_{A}(x), \mu_{B}(x)\right\}$ untuk semua $x \in X$.

- $D=A \cap B$ jika dan hanya jika $\mu_{D}(x)=\min \left\{\mu_{A}(x), \mu_{B}(x)\right\}$ untuk semua $x \in X$.

- Komplemen dari A, dinotasikan dengan $A^{c}$, didefinisikan oleh

$$
\mu_{A^{c}}(x)=1-\mu_{A}(x) \text {, untuk semua } x \in X .
$$

Perhatikan bahwa ketika jangkauan fungsi keanggotaan dibatasi pada himpunan $[0 ; 1]$, fungsifungsi ini bekerja persis seperti operator yang sesuai untuk subset himpunan crisp. Untuk penyederhanaan, akan direpresentasikan setiap subset fuzzy dengan fungsi keanggotaannya.

Proposisi 6. (Sifat aljabar dari himpunan fuzzy). Misalkan A, B dan C subset fuzzy dari himpunan semesta X. Maka

1. Hukum idempotent:

$$
A \cup A=A \operatorname{dan} A \cap A=A ;
$$

2. Hukum komutatif:

$$
A \cup B=B \cup A \operatorname{dan} A \cap B=B \cap A ;
$$

3. Hukum asosiatif:

$$
(A \cup B) \cup C=A \cup(B \cup C) \operatorname{dan}(A \cap B) \cap C=A \cap(B \cap C) ;
$$

4. Hukum absorbsi:

$$
A \cup(A \cap B)=A \operatorname{dan} A \cap(A \cup B)=A ;
$$


5. Hukum distributif:

$$
A \cup(B \cap C)=(A \cup B) \cap(B \cup C) \operatorname{dan} A \cap(B \cup C)=(A \cap B) \cup(B \cap C) ;
$$

6. Hukum involusi:

$$
\left(A^{c}\right)^{c}=A
$$

7. Hukum identitas:

$$
\begin{aligned}
& A \cup \emptyset=A \operatorname{dan} A \cap \emptyset=\emptyset ; \\
& A \cup X=X \operatorname{dan} A \cap X=A ;
\end{aligned}
$$

Dengan $\emptyset$ adalah himpunan kosong fuzzy didefinisikan dengan $\mu_{\varnothing}(x)=0$ untuk semua $x \in X$.

8. Hukum deMorgan:

$$
(A \cup B)^{c}=A^{c} \cap B^{c} \operatorname{dan}(A \cap B)^{c}=A^{c} \cup B^{c} .
$$

Untuk membuktikan proposisi tersebut, sebagai contoh, untuk membuktikan 8. misalkan $x \in X$, maka diperoleh

$$
\begin{aligned}
\mu_{(A \cup B)^{c}}(x) & =1-\mu_{A \cup B}(x) \\
& =1-\max \left\{\mu_{A}(x), \mu_{B}(x)\right\} \\
=1+\min \{ & \left.-\mu_{A}(x),-\mu_{B}(x)\right\} \\
=\min \{1- & \left.\mu_{A}(x), 1-\mu_{B}(x)\right\} \\
= & \min \left\{\mu_{A^{c}}(x), \mu_{B} c(x)\right\} \\
= & \mu_{A^{c} \cap B^{c}}(x),
\end{aligned}
$$

Dengan uraian yang sama, diperoleh

$$
\begin{aligned}
\mu_{(A \cap B)^{c}}(x) & =1-\mu_{A \cap B}(x) \\
& =1-\min \left\{\mu_{A}(x), \mu_{B}(x)\right\} \\
=1+\max \{ & \left.-\mu_{A}(x),-\mu_{B}(x)\right\} \\
=\max \{1- & \left.\mu_{A}(x), 1-\mu_{B}(x)\right\} \\
= & \max \left\{\mu_{A^{c}}(x), \mu_{B} c(x)\right\} \\
= & \mu_{A^{c} \cup B^{c}}(x),
\end{aligned}
$$

Catatan: Secara umum,

$$
A \cup A^{c} \neq X \operatorname{dan} A \cap A^{c} \neq \varnothing
$$

Definisi 7. Misalkan $f$ adalah pemetaan dari sebuah himpunan $X$ ke himpunan $Y$. Misalkan $\mu$ adalah subset fuzzy dari $X$ dan $\lambda$ adalah subset fuzzy dari $Y$. Maka, invers image (Im) $f^{-1}(\lambda)$ dari $\lambda$ adalah subset dari $X$ didefinisikan dengan $f^{-1}(\lambda)(x)=\lambda(f(x))$, untuk semua $x \in X$. Image dari $f(\mu)$ adalah subset fuzzy dari $Y$ dan didefinisikan dengan 


$$
f(\mu)(y)=\left\{\begin{array}{c}
\sup \left\{\mu(t) \mid t \in f^{-1}(y)\right\} j \text { jika } f^{-1}(y) \neq \emptyset \\
0, \text { yang lain. }
\end{array}\right.
$$

untuk semua $y \in Y$.

Selanjutnya, tidaklah sulit untuk melihat bahwa pernyataan berikut berlaku.

(1) Jika $\left\{\lambda_{i}\right\}_{i \in I}$ adalah keluarga dari subset fuzzy $Y$, maka

$$
f^{-1}\left(\bigcup_{i \in I} \lambda_{i}\right)=\bigcup_{i \in I} f^{-1}\left(\lambda_{i}\right) \operatorname{dan} f^{-1}\left(\bigcap_{i \in I} \lambda_{i}\right)=\bigcap_{i \in I} f^{-1}\left(\lambda_{i}\right)
$$

(2) Jika $\mu$ adalah subset fuzzy dari $X$ maka $\mu \subseteq f^{-1}(f(u))$. Selanjutnya, jika $f$ adalah satusatu, maka $f^{-1}(f(\mu))=\mu$.

(3) Jika $\lambda$ adalah subset fuzzy dari $Y$, maka $f\left(f^{-1}(\lambda)\right) \subseteq \lambda$. Selanjutnya, jika $f$ onto, maka $f\left(f^{-1}(\lambda)\right)=\lambda$.

Misalkan $f$ adalah pemetaan dari himpunan $X$ ke himpunan $Y$ dan $\mu$ adalah subset fuzzy dari $X$. Maka, $\mu$ disebut $f$ - invariant jika $f(x)=f(y)$ yang berarti bahwa $\mu(x)=\mu(y)$, untuk semua $x, y \in X$.

Meskipun kisaran nilai antara 0 dan 1 adalah yang paling umum digunakan untuk merepresentasikan derajat keanggotaan, setiap himpunan sebarang dengan beberapa keterurutan parsial atau keseluruhan, sebenarnya dapat digunakan. Unsur-unsur himpunan ini tidak harus berupa angka asalkan urutannya dapat diartikan mewakili berbagai kekuatan derajat keanggotaan. Fungsi keanggotaan umum ini memiliki bentuk

$$
\mu_{A}: X \rightarrow L,
$$

yang mana $L$ menyatakan himpunan yang (paling tidak) terurut parsial. Karena $L$ paling sering berupa lattice, himpunan bagian fuzzy yang didefinisikan oleh fungsi derajat keanggotaan umum ini disebut himpunan bagian L-fuzzy, di mana L dimaksudkan sebagai singkatan dari lattice.

Misalkan $(X, \leq, \mathrm{V}, \wedge)$ adalah lattice dengan elemen minimum 0 dan maksimum 1. Diberikan subset fuzzy $\mu: X \rightarrow X, \alpha-c u t$ dari $\mu$ didefinisikan dengan $\mu_{\alpha}=\{x \in X \mid \mu(x) \geq \alpha\}$, dengan $\alpha \in X$. Beberapa sifat dari $\alpha-c u t$ antara lain sebagai berikut.

Proposisi 8. Untuk beberapa subset $L-f u z z y \mu$ pada $X$, dengan $\alpha-c u t s\left\{\mu_{\alpha}\right\}_{\alpha \in X}$, pernyataan-pernyataan berikut adalah benar.

(1) Untuk semua $\alpha, \beta \in X$, jika $\alpha \leq \beta$, maka $\mu_{\beta} \subseteq \mu_{\alpha}$.

(2) Untuk semua $I \subseteq X$, berlaku $\bigcap_{\alpha \in I} \mu_{\alpha}=\mu_{\mathrm{VI}}$.

(3) $\mu_{0}=X$

Proposisi 9. Pertimbangkan suatu keluarga himpunan $\left\{\tilde{\mu}_{\alpha}\right\}_{\alpha \in X}$ yang memenuhi sifat-sifat berikut.

(1) Untuk semua $\alpha, \beta \in X$, jika $\alpha \leq \beta$, maka $\tilde{\mu}_{\beta} \subseteq \tilde{\mu}_{\alpha}$ 
(2) Untuk semua $I \subseteq X$, berlaku $\bigcap_{\alpha \in I} \tilde{\mu}_{\alpha}=\tilde{\mu}_{\mathrm{VI}}$.

(3) $\tilde{\mu}_{0}=X$.

Definisikan subset $L-f u z z y \mu$ sebagai berikut: untuk semua $x \in X, \mu(x)=\bigvee\left\{\alpha \in X \mid x \in \tilde{\mu}_{\alpha}\right\}$. Maka, untuk semua $\alpha \in X$, berlaku $\mu_{\alpha}=\tilde{\mu}_{\alpha}$.

Proposisi 10. Untuk beberapa subset $L-$ fuzzy $\mu$ dan $\lambda$ pada $X, \mu=\lambda$ jika dan hanya jika, untuk $\alpha \in X, \mu_{\alpha}=\lambda_{\alpha}$

\section{Himpunan Fuzzy Intuitionistic}

Sebagai perumuman penting dari gagasan himpunan fuzzy pada X, Atanassov memperkenalkan dalam [3] konsep himpunan fuzzy intuitionistic yang didefinisikan pada himpunan $X$ yang tidak kosong sebagai objek dengan bentuk

$$
A=\left\{\left(x, \mu_{A}(x), \lambda_{A}(x)\right) \mid x \in X\right\}
$$

Dengan fungsi $\mu_{A}: X \rightarrow[0,1]$ dan $\lambda_{A}: X \rightarrow[0,1]$ menotasikan derajat keanggotaan (yaitu $\mu_{A}(x)$ ) dan derajat non-keanggotaan (yaitu $\lambda_{A}(x)$ ) dari setiap anggota $x \in X$ terhadap himpunan $A$ beruturut-turut; dan $0 \leq \mu_{A}(x)+\lambda_{A}(x) \leq 1$ untuk setiap $x \in X$.

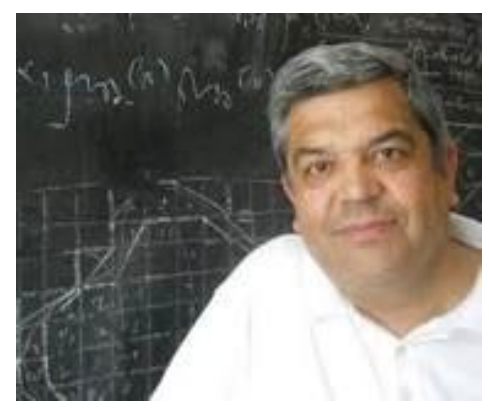

Gambar 2. K. T. Atanassov

Untuk setiap dua himpunan fuzzy intuitionistic $A$ dan $B$ pada $X$ didefinisikan (lihat [4]):

1. $A \subseteq B$ jika dan hanya jika $\mu_{A}(x) \leq \mu_{B}(x)$ dan $\lambda_{A}(x) \geq \lambda_{B}(x)$ untuk setiap $x \in X$.

2. $A^{c}=\left\{\left(x, \lambda_{A}(x), \mu_{A}(x)\right) \mid x \in X\right\}$.

3. $A \cap B=\left\{\left(x, \min \left\{\mu_{A}(x), \mu_{B}(x)\right\}, \max \left\{\lambda_{A}(x), \lambda_{B}(x)\right\}\right) \mid x \in X\right\}$.

4. $A \cup B=\left\{\left(x, \max \left\{\mu_{A}(x), \mu_{B}(x)\right\}, \min \left\{\lambda_{A}(x), \lambda_{B}(x)\right\}\right) \mid x \in X\right\}$.

5. $\square A=\left\{\left(x, \mu_{A}(x), \mu_{A}^{c}(x)\right) \mid x \in X\right\}$.

6. $\diamond A=\left\{\left(x, \lambda_{A}^{c}(x), \lambda_{A}(x)\right) \mid x \in X\right\}$.

Contoh 3. Misalkan himpunan semesta $X=\{10,100,500,1000,1200\}$. Suatu himpunan fuzzy intuitionistic "Besar" dari $X$ dinotasikan dengan $L$ dan dapat didefinisikan dengan $L=\{\langle 10,0.01,0.9\rangle,\langle 100,0.1,0.88\rangle,<500,0.4,0.5\rangle,<1000,0.8,0.1\rangle,<1200,1,0$ $>\}$, 
Dapat juga didefinisikan suatu himpunan fuzzy intuitionistic "Sangat Besar" dari $X$ dinotasikan dengan $V L$ sebagai berikut:

$\mu_{V L}(x)=\left(\mu_{L}(x)\right)^{2}$ dan $\lambda_{V L}(x)=1-\left(1-\lambda_{L}(x)\right)^{2}$,

untuk setiap $x \in X$. Sehingga,

$$
\begin{gathered}
V L=\{<10,0.0001,0.99>,<100,0.01,0.9856>,<500,0.16,0.75>,<1000,0.64,0.19 \\
>,<1200,1,0>\} .
\end{gathered}
$$

Contoh 4. Pandang himpunan semesta $\left\{a_{1}, a_{2}, a_{3}, a_{4}, a_{5}\right\}$. Misalkan $A$ dan $B$ dua himpunan fuzzy intuitionistic dari $X$ diberikan oleh

$$
\left.A=\left\{\left\langle a_{1}, 0.2,0.6\right\rangle,\left\langle a_{2}, 0.3,0.7\right\rangle,\left\langle a_{3}, 1,0\right\rangle,\left\langle a_{4}, 0.8,0.1\right\rangle,<a_{5}, 0.5,0.4\right\rangle\right\}
$$

dan

$B=\left\{\left\langle a_{1}, 0.4,0.4\right\rangle,\left\langle a_{2}, 0.5,0.2\right\rangle,\left\langle a_{3}, 0.6,0.2\right\rangle,\left\langle a_{4}, 0.1,0.7\right\rangle,\left\langle a_{5}, 0,1\right\rangle\right\}$.

maka

$$
\begin{aligned}
& A^{c}=\left\{\left\langle a_{1}, 0.6,0.2\right\rangle,\left\langle a_{2}, 0.7,0.3\right\rangle,\left\langle a_{3}, 0,1\right\rangle,\left\langle a_{4}, 0.1,0.8\right\rangle,\left\langle a_{5}, 0.4,0.5\right\rangle\right\}, \\
& A \cap B=\left\{\left\langle a_{1}, 0.2,0.6\right\rangle,\left\langle a_{2}, 0.3,0.7\right\rangle,\left\langle a_{3}, 0.6,0.2\right\rangle,\left\langle a_{4}, 0.1,0.7\right\rangle,\left\langle a_{5}, 0,1\right\rangle\right\}, \\
& A \cup B=\left\{\left\langle a_{1}, 0.4,0.4\right\rangle,\left\langle a_{2}, 0.5,0.2\right\rangle,\left\langle a_{3}, 1,0\right\rangle,\left\langle a_{4}, 0.8,0.1\right\rangle,\left\langle a_{5}, 0.5,0.4\right\rangle\right\} \text {, } \\
& \square A=\left\{\left\langle a_{1}, 0.2,0.8\right\rangle,\left\langle a_{2}, 0.3,0.7\right\rangle,\left\langle a_{3}, 1,0\right\rangle,\left\langle a_{4}, 0.8,0.2\right\rangle,\left\langle a_{5}, 0.5,0.5\right\rangle\right\}, \\
& \diamond B=\left\{\left\langle a_{1}, 0.6,0.4\right\rangle,\left\langle a_{2}, 0.8,0.2\right\rangle,\left\langle a_{3}, 0.8,0.2\right\rangle,\left\langle a_{4}, 0.3,0.7\right\rangle,\left\langle a_{5}, 0,1\right\rangle\right\} .
\end{aligned}
$$

\section{$4 \quad$ Rough Set}

Konsep rough set pertama kali diperkenalkan oleh Pawlak [5], [6] sebagai alat formal untuk memodelkan dan memproses informasi lengkap di sistem informasi. Teori rough set merupakan perluasan dari teori himpunan, yaitu suatu himpunan bagian dari semesta dideskripsikan oleh suatu pasangan dari himpunan asli yang dinamakan himpunan aproksimasi atas dan bawah. Kunci gagasan pada model rough set tersebut adalah relasi ekivalen, yaitu relasi refleksif, simetri dan transitif. Kelas ekivalen adalah fondasi dalam mengkonstruksi aproksimasi bawah dan atas. Aproksimasi bawah dari suatu himpunan adalah gabungan dari seluruh kelas ekivalen yang merupakan himpunan bagian dari himpunan tersebut, dan aproksimasi atas adalah gabungan seluruh kelas ekivalen yang irisannya tidak kosong dengan himpunan tersebut. Penjelasan detailnya dapat dibaca di [7], [8]. 


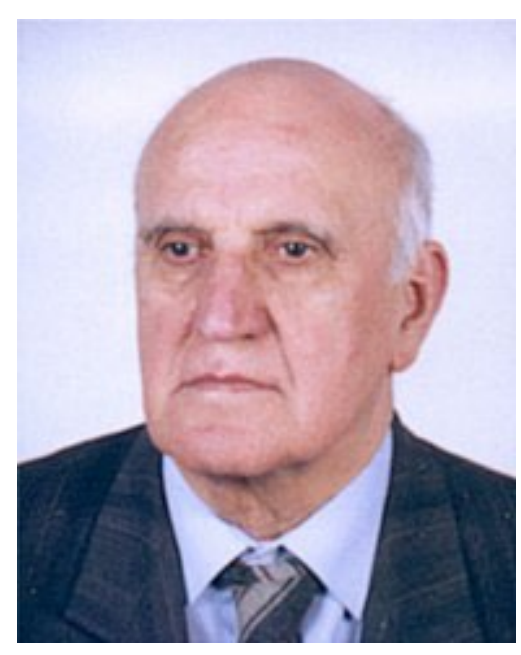

Gambar 3. Z. Pawlak

Misalkan $U$ suatu himpunan tak kosong. Suatu partisi atau klasifikasi dari $U$ adalah rumpun $\mathcal{P}$ dengan $\mathcal{P}$ adalah kumpulan himpunan bagian tak kosong dari $U$ (power-set) sedemikian hingga setiap anggota dari $U$ termuat di tepat satu anggota $\mathcal{P}$. Ingat bahwa suatu relasi ekivalen $\theta$ pada $U$ adalah refleksif, simetri dan transitif, yaitu untuk setiap $x, y, z \in U$, diperoleh

$$
\begin{array}{cl}
x \theta x & \text { Refleksif } \\
\text { jika } x \theta y \text { maka } y \theta x & \text { Simetri } \\
\text { jika } x \theta y \text { dan } y \theta z \text { maka } x \theta z & \text { Transitif }
\end{array}
$$

setiap partisi $\mathcal{P}$ menghasilkan satu relasi ekivalen $\theta$ pada $U$ dengan menetapkan

$$
x \theta y \Leftrightarrow x \text { dan } y \text { terletak pada kelas yang sama di } \mathcal{P} \text {. }
$$

Sebaliknya, setiap relasi ekivalen $\theta$ menghasilkan suatu partisi $\mathcal{P}$ dengan kelas ekivalen $[x]_{\theta}=$ $\{y \in U \mid x \theta y\}$.

Beberapa notasi berikut akan digunakan dalam artikel ini. Diberikan suatu semesta $U$, dengan $\mathcal{P}$ dinotasikan sebagai power-set dari $U$. jika $\theta$ adalah relasi ekivalen pada $U$ maka untuk setiap $x \in U,[x]_{\theta}$ bermakna kelas ekivalen dari $x$. Untuk setiap $X \subseteq U, X^{C}$ dinotasikan sebagai komplemen dari $X$, yaitu himpunan $U \backslash X$.

Misalkan $U$ himpunan semesta dan $\rho$ relasi ekivalen dari $U$. Diberikan sebarang himpunan $A \subseteq U$, maka tidak mungkin untuk mendeskripsikan $A$ secara tepat menggunakan kelas ekivalen dari $\rho$. Maknanya adalah bahwa informasi yang tersedia masih belum mencukupi untuk mendeskripsikan $A$ secara tepat. Pada kasus ini, $A$ dapat digambarkan oleh pasangan aproksimasi bawah dan atas

$$
\underline{\operatorname{app}}(A):=\bigcup_{[a]_{\rho} \subseteq A}[a]_{\rho} \operatorname{dan} \overline{\operatorname{app}}(A):=\bigcup_{[a]_{\rho} \cap A \neq \emptyset}[a]_{\rho},
$$

Dengan $[a]_{\rho}=\{b \mid a \rho b\}$ adalah kelas ekivalen yang memuat $a$. Aproksimasi bawah $\underline{\operatorname{app}}(A)$ adalah gabungan dari seluruh kelas ekivalen yang termuat di $A$. Aproksimasi atas $\overline{\operatorname{app}}(A)$ adalah 
gabungan seluruh kelas ekivalen yang irisannya dengan $A$ tidak kosong. Anggota aproksimasi bawah pasti anggota dari $A$ sedangkan anggota aproksimasi atas adalah mungkin anggota dari $A$. Aproksimasi bawah dan atas dapat dinyatakan sebagai berikut:

$$
\underline{\operatorname{app}}(A)=\left\{a \in U \mid[a]_{\rho} \subseteq A\right\} \text { dan } \overline{\operatorname{app}}(A)=\left\{a \in U \mid[a]_{\rho} \cap A \neq \emptyset\right\} .
$$

Selisih antara aproksimasi atas dan bawah dinamakan daerah batas- $\rho$ dari $A$ dan dinotasikan dengan $\widehat{a p p(A)}$. Himpunan bagian $X$ dari $U$ dikatakan definable jika $\underline{\operatorname{app}}(X)=\overline{\operatorname{app}}(X)$. Jika $X \subseteq$ $U$ diberikan suatu sifat $P$ dan $x \in U$, maka

1. $x \in \underline{\operatorname{app}}(X)$ bermakna $x$ pasti memiliki sifat $P$.

2. $x \in \overline{\operatorname{app}}(X)$ bermakna $x$ mungkin memiliki sifat $P$.

3. $x \in U \backslash \overline{a p p}(X)$ bermakna $x$ tidak mungkin memiliki sifat $P$.

Proposisi 11. Dari uraian diatas, diperoleh

1. $\underline{\operatorname{app}}(A) \subseteq A \subseteq \overline{\operatorname{app}}(A)$;

2. $\operatorname{app}(\varnothing)=\varnothing=\overline{\operatorname{app}}(\varnothing)$;

3. $\operatorname{app}(U)=U=\overline{\operatorname{app}}(U)$;

4. Jika $A \subseteq B$, maka $\underline{\operatorname{app}}(A) \subseteq \underline{\operatorname{app}}(B)$ dan $\overline{\operatorname{app}}(A) \subseteq \overline{\operatorname{app}}(B)$;

5. $\underline{\operatorname{app}}(\underline{\operatorname{app}}(A))=\underline{\operatorname{app}}(A)$;

6. $\overline{a p p}(\overline{a p p}(A))=\overline{a p p}(A)$;

7. $\overline{\operatorname{app}}(\underline{\operatorname{app}}(A))=\underline{\operatorname{app}}(A)$;

8. $\quad \underline{\operatorname{app}}(\overline{\operatorname{app}}(A))=\overline{\operatorname{app}}(A)$;

9. $\underline{\operatorname{app}}(A)=\left(\left(\overline{\operatorname{app}}\left(A^{C}\right)\right)^{C}\right.$;

10. $\left.\overline{\operatorname{app}}(A)=\underline{\operatorname{app}}\left(A^{C}\right)\right)^{C}$;

11. $\underline{\operatorname{app}}(A \cap B)=\underline{\operatorname{app}}(A) \cap \underline{\operatorname{app}}(B)$;

12. $\overline{\operatorname{app}}(A \cap B) \subseteq \overline{\operatorname{app}}(A) \cap \overline{\operatorname{app}}(B)$;

13. $\underline{\operatorname{app}}(A \cup B) \supseteq \underline{\operatorname{app}}(A) \cup \underline{\operatorname{app}}(B)$;

14. $\overline{a p p}(A \cup B)=\overline{a p p}(A) \cup \overline{a p p}(B)$.

Suatu pasangan $(U, \rho)$ dengan $U \neq \emptyset$ dan $\rho$ adalah suatu relasi ekivalen pada $U$, dinamakan ruang aproksimasi. Untuk suatu ruang aproksimasi $(U, \rho)$ dengan aproksimasi pada $(U, \rho)$ adalah suatu pemetaan app: $\mathcal{P}(U) \rightarrow \mathcal{P}(U) \times \mathcal{P}(U)$ yang didefinisikan untuk setiap $X \in \mathcal{P}(U)$, yaitu

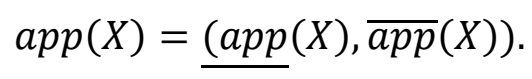

Persamaan rough set antara himpunan-himpunan didefinisikan sebagai berikut: 
Untuk sebarang $A, B \subseteq U$, berlaku

$$
A \approx B \Leftrightarrow \underline{\operatorname{app}}(A)=\underline{\operatorname{app}}(B) \operatorname{dan} \overline{\operatorname{app}}(A)=\overline{\operatorname{app}}(B) .
$$

Tampak jelas bahwa $\approx$ adalah suatu relasi ekivalen pada $\mathcal{P}(U)$. Sebarang kelas ekivalen pada relasi $\approx$ dinamakan rough set. Dinotasikan rumpun seluruh rough set dengan

$$
\mathcal{R}^{0}=\left\{[X]_{\approx} \mid X \subseteq U\right\} .
$$

Oleh karena itu, untuk suatu ruang aproksimasi $(U, \rho)$, pasangan $(A, B) \in \mathcal{P}(U) \times \mathcal{P}(U)$ adalah rough set jika dan hanya jika $(A, B)=\operatorname{app}(X)$ untuk suatu $X \in \mathcal{P}(U)$.

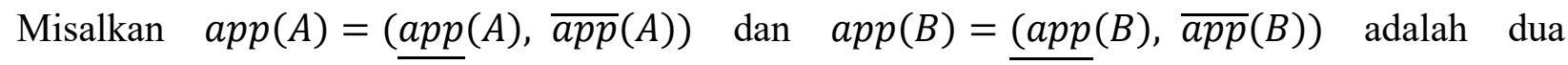
himpunan rough set pada ruang aproksimasi $(U, \rho)$. Maka, himpunan gabungan, irisan, relasi inklusi, komplemen dan selisih antara rough set ditetapkan sebagai berikut:

1. $\operatorname{app}(A) \sqcup \operatorname{app}(B):=(\operatorname{app}(A) \cup \underline{\operatorname{app}}(B), \overline{\operatorname{app}}(A) \cup \overline{\operatorname{app}}(B))$,

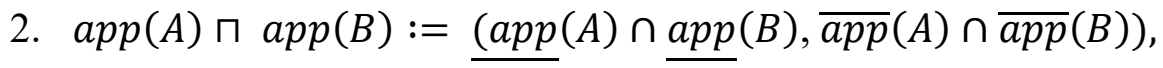

3. $\operatorname{app}(A) \sqsubseteq \operatorname{app}(B): \Leftrightarrow \operatorname{app}(A) \cap \operatorname{app}(B)=\operatorname{app}(A)$.

Jika $\operatorname{app}(A) \sqsubseteq \operatorname{app}(B)$, dikatakan $\operatorname{app}(A)$ adalah suatu himpunan bagian rough set. Sehingga antara rough set $\operatorname{app}(A)$ dan $\operatorname{app}(B)$, dapat dinyatakan

$\operatorname{app}(A) \sqsubseteq \operatorname{app}(B)$ jika dan hanya jika $\underline{\operatorname{app}}(A) \subseteq \underline{\operatorname{app}}(B)$ dan $\overline{\operatorname{app}}(A) \subseteq \overline{\operatorname{app}}(B)$.

Sifat inklusi pada rough set ini juga berlaku untuk seluruh sifat inklusi pada himpunan. complement rough dari $\operatorname{app}(A)$ dinotasikan dengan $\operatorname{app}^{C}(A)$ dan didefinisikan dengan

$$
\operatorname{app}^{C}(A):=(U \backslash \overline{\operatorname{app}}(A), U \backslash \underline{\operatorname{app}}(A)) .
$$

Juga didefinisikan $\operatorname{app}(A) \backslash \operatorname{app}(B)$ sebagai berikut

$$
\begin{aligned}
\operatorname{app}(A) \backslash \operatorname{app}(B) & :=\operatorname{app}(A) \cap \operatorname{app}^{C}(B) \\
& =(\underline{\operatorname{app}}(A) \backslash \overline{\operatorname{app}}(B), \overline{\operatorname{app}}(A) \backslash \underline{\operatorname{app}}(B)) .
\end{aligned}
$$

J. Pomykala dan J. A. Pomykala [9] menunjukkan bahwa himpunan dari rough set membentuk aljabar Stone.

Lemma 12. [9 Lemma 4] Misalkan $(U, \rho)$ ruang aproksimasi dan $\mathcal{R}^{0}$ rumpun dari rough set. Maka aljabar $\left(\mathcal{R}^{0}, \sqcup, \Pi\right)$ adalah lattice distributive lengkap.

Lattice $\left(\mathcal{R}^{0}, \sqcup, \sqcap\right)$ bersifat terbatas, dengan $0=[\varnothing]_{\approx}$ adalah anggota terkecil dan $1=[U]_{\approx}$ adalah anggota terbesar.

Ingat bahwa pada lattice terbatas $(L, \vee, \wedge, 0,1), x$ adalah komplemen dari $y$ jika dan hanya jika $x \wedge y=0$ dan $x \vee y=1$.

Mudah dilihat bahwa $\mathcal{R}^{0}$ bukan lattice komplemen [10]. 
Misalkan $L$ lattice yang memuat 0 ; anggota $x^{*}$ adalah pseudo-komplemen dari $x \in L$ jika dan hanya jika $x \wedge x^{*}=0$ dan $x \wedge z=0$ mengakibatkan $z \leq x^{*}$. Lattice pseudo-komplemen adalah salah satu dimana setiap anggotanya mempunyai pseudo-komplemen,

Dapat didefinisikan operasi pada $\mathcal{R}^{*}$, sebagai berikut: untuk setiap $\mathcal{X} \in \mathcal{R}^{*}$,

$$
X^{*}=[U-\bar{X}]_{\approx}
$$

Maka $\mathcal{X}^{*}$ adalah pseudo-komplemen dari $\mathcal{X}$.

Lemma 13. [9, Lemma 7] ( $\left.\mathcal{R}^{0}, \sqcup, \Pi, *\right)$ adalah lattice pseudo-komplemen.

Lattice distributive dengan pseudo-komplemen dinamakan aljabar Stone jika dan hanya jika lattice tersebut memenuhi kesamaan identitas $a^{*} \vee a^{* *}=1$.

Lemma 14. [9, Lemma 8] Pada aljabar $\left(\mathcal{R}^{0}, \sqcup, \Pi, *, 0,1\right)$ identitas Stone adalah lattice valid. Hasil-hasil di atas dapat diringkas dalam teorema berikut.

Teorema 15. [9, Teorema 1] Misalkan $\mathcal{R}^{0}$ adalah rumpun dari rough set. Maka, aljabar $\left(\mathcal{R}^{0}, \sqcup\right.$, $\Pi, *, 0,1)$ adalah lengkap, aljabar Stone atomic.

Aljabar Stone rangkap adalah aljabar $(\mathrm{L},+, \cdot *, 0,1)$ sedemikian hingga $(\mathrm{L},+, \cdot, 0,1)$ adalah lattice distributive terbatas, $*$ adalah pseudo-komplemen, hukum Stone terpenuhi (yaitu $a^{*}+a^{* *}=1$ ), + adalah pseudo-komplemen dual (yaitu $x \geq a^{+} \Leftrightarrow x+a=1$, dan hukum dual Stone terpenuhi (yaitu $a^{+} . a^{++}=0$ ). Aljabar Stone regular jika $a^{+}=b^{+}$dan $a^{*}=b^{*}$ mengakibatkan $a=b$. Pembaca dapat melihat [11] untuk penjelasan dasar mengenai aljabar Stone rangkap.

Teorema 16. [12, Teorema 2.1] $\mathcal{R}^{0}$ adalah aljabar Stone pada setiap ruang aproksimasi.

\section{Rough Set Probabilistik}

Gagasan probabilistik bersyarat adalah alat dasar teori probabilistik, dan ini disayangkan bahwa kesederhanaannya agak dikaburkan oleh istilah-istilah yang justru sulit dipahami.

Misalkan $X$ adalah suatu kejadian dengan peluang positif. Untuk suatu sebarang kejadian $A$ dapat ditulis

$$
P(A \mid X)=\frac{P(A \cap X)}{P(X)}
$$

Kuantitas yang ditentukan disebut probabilitas bersyarat dari $A$ terhadap hipotesis $X$. Ketika seluruh sampel mempunyai peluang positif, maka $P(A \mid X)$ adalah rasio $\frac{|A \cap X|}{|X|}$ dari jumlah sampel bersama $A$ dan $X$. Seluruh teorema probablilstik adalah valid termasuk probablilistik bersyarat sehubungan dengan hipotesis $X$ tertentu. Misalnya saja teorema fundamental untuk peluang terjadinya $A$ atau $B$ atau keduanya dalam persamaan 


$$
P(A \cup B \mid X)=P(A \mid X)+P(B \mid X)-P(A \cap B \mid X) .
$$

Untuk setiap $A \subseteq U$, fungsi keanggotaan rough set didefinisikan dengan

$$
\mu_{A}(x)=\frac{\left|A \cap[x]_{\rho}\right|}{\left|[x]_{\rho}\right|} .
$$

Berdasarkan definisi di atas, anggota yang terletak pada kelas ekivalen yang sama mempunyai derajat keanggotaan yang sama. Dapat dilihat bahwa terdapat similaritas antara fungsi keanggotaan rough set dengan probabilistik bersyarat. Nilai keanggotaan rough set $\mu_{A}(x)$ dapat diartikan sebagai peluang $x$ yang termuat di $A$ mengingat $x$ adalah anggota suatu kelas ekivalen. Berdasarkan pengertian ini, diperoleh gagasan rough set probabilistik. Dengan menggunakan hukum probabilitas, operasi irisan dan gabungan rough set probabilistik tidak berlaku. Namun dapat diperoleh:

1. $\mu_{A}(x)=1 \Leftrightarrow x \in \underline{\operatorname{app}}(A)$,

2. $\mu_{A}(x)=0 \Leftrightarrow x \in \underline{\operatorname{app}}\left(A^{C}\right)$,

3. $0<\mu_{A}(x)<1 \Leftrightarrow x \in \widehat{\operatorname{app}(A)}$.,

4. $\mu_{A}(x)=1-\mu_{A^{C}}$,

5. $\mu_{A \cup B}=\mu_{A}(x)+\mu_{B}(x)-\mu_{A \cap B}(x)$,

6. $\max \left\{\mu_{A}(x), \mu_{B}(x)\right\} \leq \mu_{A \cup B} \leq \min \left\{1, \mu_{A}(x)+\mu_{B}(x)\right\}$,

7. $\mu_{A \cap B}(x) \leq \min \left\{\mu_{A}(x), \mu_{B}(x)\right\}$,

8. Untuk setiap pasangan saling asing koleksi $P$ dari himpunan bagian

$$
\mu_{\cup P}(x)=\sum\left\{\mu_{Y}(x) \mid Y \in P\right\}
$$

Aksioma diatas diperoleh dari sifat probabilitas.

Dengan fungsi keanggotaan rough set, dapat dilihat bahwa rough set probabilistik sebagai bentuk khusus dari himpunan fuzzy. Dengan menggambar kaitan antara dua teori ini, operator yang tidak berlaku pada rough set probabilistik dapat memberikan banyak wawasan mengenai definisi operator himpunan fuzzy.

Gagasan rough set probabilistik dapat dihubungkan ke aljabar rough set $-\rho(\mathcal{P}(U), \approx, \Pi$, $\sqcup, \neg,[\varnothing]_{\approx},[U]_{\approx}$ ). Dua anggota yang mempunyai fungsi keanggotaan yang sama, yaitu $A \approx B$, maka tidak dapat disimpulkan $A$ dan $B$ mempunyai fungsi keanggotaan yang sama, sehingga $\mu_{A} \neq$ $\mu_{B}$. Misalkan $c\left(\mu_{A}\right)$ dan $s\left(\mu_{A}\right)$ masing-masing menotasikan inti dan tumpuan dari $\mu_{A}$ yang didefinisikan dengan

$$
\begin{aligned}
& c\left(\mu_{A}\right)=\left\{x \mid \mu_{A}(x)=1\right\}, \\
& s\left(\mu_{A}\right)=\left\{x \mid \mu_{A}(x)>0\right\} .
\end{aligned}
$$


Berdasarkan sifat (1) dan (2), dapat diperiksa bahwa jika $A \approx B$ maka $c\left(\mu_{A}\right)=c\left(\mu_{B}\right)$ dan $s\left(\mu_{A}\right)=s\left(\mu_{B}\right)$. Dengan kata lain, suatu rough set- $\rho$ adalah rumpun rough set probabilistik dengan inti dan tumpuan yang sama.

\section{Simpulan}

Pada paper ini telah dibahas beberapa kajian mengenai himpunan fuzzy, rough set dan perluasannya yang meliputi pengertian tentang crisp sets dan fungsi karakteristik, himpunan fuzzy intuitionistic, dan rough set probabilistik.

\section{Ucapan terima kasih:}

Paper ini dipersiapkan pada saat penulis pertama melakukan kunjungan ke Departemen Matematika ITS dalam rangka mengikuti program World Class Professor tahun 2019. Terima kasih disampaikan kepada Kementerian Riset, Teknologi dan Pendidikan Tinggi yang telah membiayai program ini.

\section{Daftar Pustaka}

[1] L.A.Zadeh, "Fuzzy Sets.," Information and Control, vol. 8, pp. 338-353, 1965.

[2] B. Davvaz and I Cristea, "Fuzzy Algebraic Hyperstructures: An introduction," Studies in Fuzziness and Soft Computing, vol. 321, 2015.

[3] K.T. Atanassov, "Intuitionistic Fuzzy Sets," Fuzzy Sets and Systems, vol. 20, pp. 87-96, 1986.

[4] K.T. Atanassov, "New Operations Defined over the Intuitionistic Fuzzy Sets," Fuzzy Sets and Systems, vol. 61, pp. 137-142, 1994.

[5] Z. Pawlak, "Rough Sets,” Int. J. Comput. Inf. Sci., vol. 11, pp. 341-356, 1982.

[6] Z. Pawlak, "Rough Sets - Theoretical Aspects of Reasoning about Data," Kluwer Acad. Publ. Dordr., 1991.

[7] B. Davvaz, "Roughness in Rings," Information Sciences., vol. 164, no. 1-4, pp. 147-163, 2004.

[8] B. Davvaz, "Rough Algebraic Structures Corresponding to Ring Theory," Algebraic. Methods in General Rough Sets, Trends Math., Birkhuser/Springer, Cham, pp. 657-695, 2018.

[9] J. Pomykala and J. A. Pomykala, "The Stone Algebra of Rough Sets," Bull. Polish Acad. Sci. Math, vol. 36, pp. 495-508, 1988.

[10] T. Iwinski, “Algebraic Approach to Rough Sets," Bull. Polish Acad. Sci. Math, vol. 35, pp. 673-683, 1987. 
[11] G. Gratzer, "Lattice Theory: First Concepts and Distributive Lattices.," W. H. Freeman and Co., San Fransisco, Calif., pp. xv+212, 1971.

[12] S. Comer, "On Connections between Information Systems, Rough Sets and Algebraic Logic,” Banach Center Publication, Warsaw, vol. 28, pp. 117-124, 1993. 